International Journal of Engineering \& Technology, $7(3.29)(2018) 177-179$
SPC
International Journal of Engineering \& Technology
Website: www.sciencepubco.com/index.php/IJET
Research paper

\title{
Best practices in grievance handling mechanism: a study in Kerala
}

\author{
Adithi Pradeep $^{1}{ }^{*}$, Alfiya Niha ${ }^{1}$, Gopika Gopan ${ }^{1}$, Vinod Kumar $K^{1}$ \\ ${ }^{1}$ Department of Commerce and Management, Amrita School of Arts and Sciences Amrita Vishwa vidyapeetham1234 \\ *Corresponding author E-mail: alfiya.nihar@gmail.com
}

\begin{abstract}
In the present world, grievance in workplace is a common phenomenon. Grievance handling is of great importance to the human resource management sector as it will directly affect the work force of the company; unless it is taken care of in the right time, in the right manner. This study is focused on methods to implement this effectively and the responses of various employees in HOMCO have been taken for the assessment of the current system. A study on grievance handling mechanism was done at the Kerala State Homoeopathic Co-Operative Pharmacy (HOMCO). The HOMCO is engaged in manufacturing and sale of Homoeopathic Medicines. It is the sole supplier of Homoeopathic Medicines to hospitals since 1980. "Grievance Handling Mechanism" at The Kerala State Homoeopathic Co-Operative Pharmacy Limited is undertaken to make an exploration into the grievances faced by employees and to find possible solutions to increase the efficiency of the system.
\end{abstract}

Keywords: Grievance; Employee Satisfaction; Grievance Handling.

\section{Introduction}

A study on grievance handling mechanism was done at The Kerala State Homoeopathic Co-Operative Pharmacy (HOMCO). The $\mathrm{HOMCO}$ is engaged in manufacturing and sale of Homoeopathic Medicines. It is the sole supplier of Homoeopathic Medicines to hospitals and dispensaries under the department of Homoeopathy Kerala since 1980. The HOMCO is supplying medicines to over 20 states all over India and has access to export markets. The HOMCO is registered in 1975 under Co-operative Societies Act 1969. The Pharmacy efficiently serves all kind of customers through the wide network of distributors from different parts of India. For the purpose of the study 50 samples were selected from the population of 100 employees. The project study was conducted about 30 days from 22nd November to 22nd December. When the draw backs are resolved in addressing the employee grievance in the company then the employee's grievance can be reduced in the organization and the employees can also increase a relationship between supervisor and coworker and that is the main aim of the study.

\section{Literature review}

A study by Zulkiflee Bin Daurd, Khulida Kirana Yahya, Mohd faizal Mosh. Isa, Wan Shakizah Wan Mohd Noor on the influence of HOD 'S on electing grievance Handling methods. It tries to analyze the types of grievance styles that are existing which include integration style, Obliging style, Compromising style, Dominating style, Avoiding style. The study also gives a brief on personality, which includes extraversion, agreeableness, conscientious, emotional stability versus neuroticism, openness to experience. It investigates the effect on independent variables on justice, ethical ideologies, personality, training and experience. The data analysis is carried on the basis of the respondents profile as well as on basis of factor analysis. The relationship between managers personality and the selection of grievance handling styles, styles adopted by HOD'S are also discussed.

Dr G Balamurugan, V.Shenbagopandian (April 2016) conducted a study on Measures in Handling Grievances from a theoretical perspective. The study focuses on examining the bond between employer and employees, to know the grievances met by the employees, also to find the redressal process taken out by the management. It explains about the grievance procedure with regard to HR handbook and about the grievance, redressal grievances should be settled so that the workers get the essential sense of satisfaction. An analysis on "Grievance Handling mechanism and its effectiveness" by Ms.G.Ramya MRS K Shenbahan It deals with work related grievance, factors affecting individual grievance handling, factors impacting general grievance handling. It emphasis on the socio demographic details of the employees, to know how grievance handling system has led to a favorable attitude towards the management and to study the level of satisfaction towards the grievance handling process. A study conducted by Dr.V.Mohana Sundaram, on grievance handling procedure at HEME industries ltd. Hosur. The study determines the awareness of the employees to know about the grievance handling procedure, to know the satisfication level of employees with the current grievance handling procedure following the institute to understand the cause of grievance at the industry. The study reveals that the employees have a perception that employers must be able to understand and predict the drawbacks and bring up remedies before it get worse.

\section{Objectives of the study}

- To study on effectiveness of grievance handling system of HOMCO.

- To know whether the employees are satisfied with the current grievance management and how they are benefited. 
- To understand various causes of grievance \& it effect on the smooth functioning of the company.

- To know about various grievances handling measure adopted in the organization.

- To identify whether the employees are aware of the grievance handling mechanism.

\section{Methods of data collection}

The study has been conducted using two sources of data collection. The data were collected with the help of interviews and observations. Two sources are used for collection of data:

Primary Data

The primary data are collected through an interview method with the managers of the concerned department. Then interactions with the employees were done in order to collect data regarding the grievances of the employees.

The primary data is collected through:

- Questionnaire

- Observations

- Interview

\subsection{Secondary data}

Secondary data are those which have already been collected by some other person and which are passed through the statistical machines at least once.

The secondary data is collected through:

- Publications

- Websites

\subsection{Limitations of the study}

The time duration of the period was very short. It's not possible to do fully justice to the study in this short time.

The study was conducted among the selected employees and hence the study may not be generalized.

Possibility of biased information.

It was difficult to gather information due to secrecy.

Entry to some organizational department was denied.

Some employees were not ready to cooperate in completing the interview.

\section{Grievnce Procedure}

The grievance procedures differ from organization to organization The employees should first try to solve the issue informally. In cases where it does not work out, the employees can follow the step by step grievance procedure as prescribed in their company.

Generally, two types of systems are observed in organizations: Open Door Policy: In this case the employees are encouraged to walk into the top management's rooms and get their grievance addressed directly. It builds trust between the employee and the organization. But, it is difficult to be implemented effectively in large organizations. Also, it is difficult to be implemented for employees like laborers, as they are generally not very comfortable talking to the top management themselves.

Step Ladder Policy: In this case, an employee raises his concern to his supervisor. In case he is not satisfied with the decision of his supervisor he can put his problem in front of higher officials.

\section{Data analysis and interpretation}

\subsection{Percentage analysis}

Table 1: Showing Age Group of Respondents

\begin{tabular}{|c|c|c|c|}
\hline $\begin{array}{c}\text { SL } \\
\text { NO }\end{array}$ & RESPONSES & $\begin{array}{c}\text { NO: OF } \\
\text { RESPONDENTS }\end{array}$ & $\begin{array}{c}\text { PERT } \\
\text { \% }\end{array}$ \\
\hline 1 & YES & 14 & 28 \\
\hline 2 & NO & 36 & 72 \\
\hline & TOTAL & $\mathbf{5 0}$ & $\mathbf{1 0 0}$ \\
\hline
\end{tabular}

Interpretation

From the table above analysis, it can be inferred that $16 \%$ of the respondents are between the age group of $25-30,60 \%$ of respondents are between $31-40$ and $24 \%$ of respondents are between the age group of $41-50$.

Awareness of Grievance Handling Procedure in the Organization

Table 2:.Grievance Handling Procedure in the Organization

\begin{tabular}{|c|c|c|c|}
\hline $\begin{array}{c}\text { SL } \\
\text { NO }\end{array}$ & RESPONSES & $\begin{array}{c}\text { NO: OF } \\
\text { RESPONDENTS }\end{array}$ & $\begin{array}{c}\text { PERCENTAGE } \\
\%\end{array}$ \\
\hline 1 & $25-30$ & 8 & 16 \\
\hline 2 & $31-40$ & 30 & 60 \\
\hline 3 & $41-50$ & 12 & 24 \\
\hline & TOTAL & $\mathbf{5 0}$ & $\mathbf{1 0 0}$ \\
\hline
\end{tabular}

Interpretation from the above analysis, it can be inferred that $28 \%$ of respondents are aware about the grievance handling procedure in the organization and $72 \%$ of respondents are not aware. Causes of Employee's Grievance

Table 3: Showing Causes of Employee's Grievance

\begin{tabular}{|c|c|c|c|}
\hline $\begin{array}{c}\text { SL } \\
\text { NO }\end{array}$ & RESPONSES & $\begin{array}{c}\text { NO: OF } \\
\text { RESPONDENTS }\end{array}$ & $\begin{array}{c}\text { PERCENTAGE } \\
\%\end{array}$ \\
\hline 1 & YES & 14 & 28 \\
\hline 2 & NO & 36 & 72 \\
\hline & TOTAL & $\mathbf{5 0}$ & $\mathbf{1 0 0}$ \\
\hline
\end{tabular}

Interpretation from the analysis above, it can be inferred that $56 \%$ of respondent's grievance are related to work environment and $0 \%$ of respondents are related to salary.

What The Respondents Do If the Decision Is Not Favorable to Them.

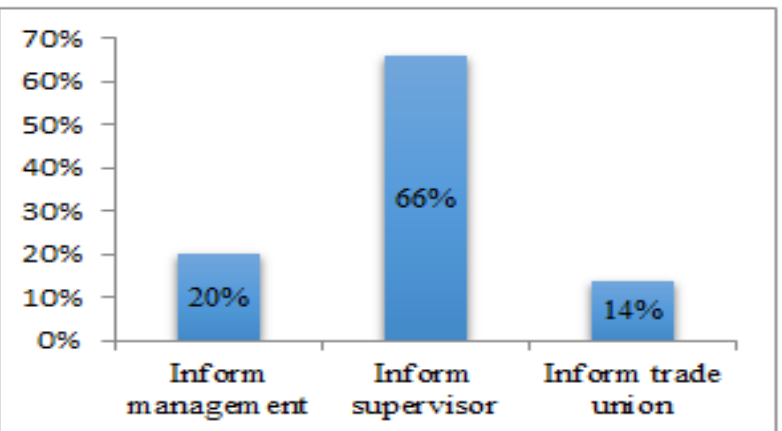

Fig. 1: Showing What the Respondents Do If the Decision is Not Favorable to Them.

Interpretation From the above analysis, it is inferred that $66 \%$ of respondents inform supervisor if the decision is not favorable, $20 \%$ respondents inform management and $14 \%$ respondents inform the trade union.

Respondent's opinion regarding record maintenance of each grievance.

Table 4: Respondents Opinion Regarding Record Maintenance of Each Grievance

\begin{tabular}{|c|c|c|c|}
\hline $\begin{array}{c}\text { SL } \\
\text { NO }\end{array}$ & RESPONSES & $\begin{array}{c}\text { NO: OF } \\
\text { RESPONDENTS }\end{array}$ & $\begin{array}{c}\text { PERCENTAGE } \\
\%\end{array}$ \\
\hline 1 & $\begin{array}{c}\text { Work } \\
\text { environment }\end{array}$ & 28 & 56 \\
\hline 2 & Supervision & 16 & 32 \\
\hline 3 & Salary & 0 & 0 \\
\hline 4 & Work group & 6 & 12 \\
\hline & TOTAL & $\mathbf{5 0}$ & $\mathbf{1 0 0}$ \\
\hline
\end{tabular}

Interpretation

From the analysis above, it can be inferred that $68 \%$ respondents states that proper records are maintained on each grievance and $32 \%$ of respondents states that proper records are not 1 maintained. 
Showing the satisfaction level towards work schedule of the company

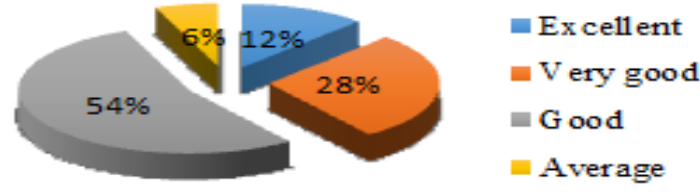

Fig. 2: Showing the Satisfaction Level towards Work Schedule of the Company.

\section{Interpretation}

From the above analysis, it is inferred that $54 \%$ respondents reported good about their work schedule of the company and $6 \%$ of respondents reported average about their work schedule.

Whether grievance redressal is one of the major component of job satisfaction.

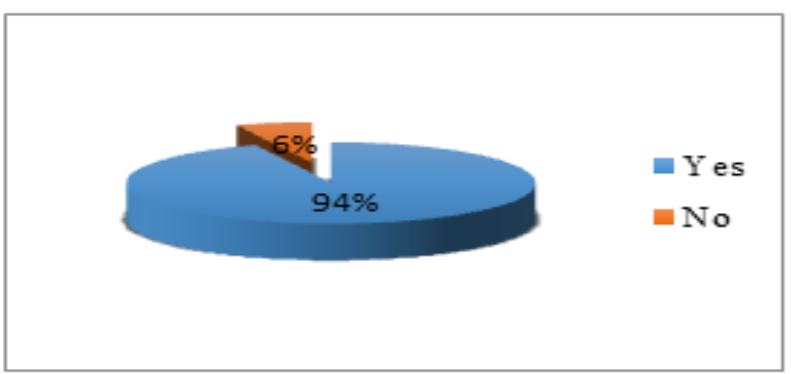

Fig. 3: Showing Whether Grievance Redressal is One of the Major Component of Job Satisfaction.

\section{Interpretation}

From the above analysis, it is inferred that $94 \%$ of respondent's states that grievance redressal is one the major component of job satisfaction and $6 \%$ of respondent's states that grievance redressal is not a major component of job satisfaction.

Respondent's opinion regarding the decision taken by the top management to their grievance is satisfactory.

Table 5: Respondents Opinion Regarding the Decision Taken by the Top Management to their Grievance is Satisfactory

\begin{tabular}{llll}
\hline S1 No & Responses & No: Of Respondents & Percentage \% \\
\hline 1 & Highly Satisfied & 5 & 10 \\
2 & Moderately Satisfied & 14 & 28 \\
3 & Satisfied & 25 & 50 \\
4 & Dissatisfied & 6 & 12 \\
& Total & 50 & 100 \\
\hline
\end{tabular}

\section{Interpretation}

From the above analysis, it is inferred that $25 \%$ of respondents are not satisfied by the existing grievance settlement system in the organization, $6 \%$ of respondents are dissatisfied.

\subsection{Findings}

Most of the respondents communicate their grievances to head of the department.

- Majority of the respondents are not aware about the grievance handling procedure in the organization.

- All most all respondents state that their grievances are related to work environment.

- $84 \%$ respondents stated that higher authority listens to their grievance and $4 \%$ respondents stated that the higher authority shouts at them.

- Majority of the respondents are satisfied towards the solution provided by the management.
- $50 \%$ of respondents reported that superior takes 2 weeks on a complaint and $4 \%$ respondents reported that superior takes indefinite period.

- Majority of respondents had faced grievance in the organization.

- Most of the respondents file grievance as group. $48 \%$ of respondents stated that their supervisors are highly skilled and $16 \%$ of respondents stated that the supervisors are not skilled.

- Most of the respondents communicate their grievance through oral form.

- $86 \%$ of respondents stated that upper management pressure is a reason for grievance and $14 \%$ of respondents stated that it is not a reason for their grievance in the company.

- Majority of the respondent's states that proper records are maintained on each grievance.

- Most of the respondent's state that grievance redressal is one of the major components of job satisfaction.

- Most of the respondents are satisfied by the existing grievance settlement system.

- $54 \%$ of respondents reported good bout1 their work schedule of the company and $6 \%$ of respondents reported average about their work schedule.

Suggestion

- Informal counseling should be conducted. It helps to address and manage grievance in the workplace.

- The company should use new method of performance appraisal and the company should evaluate their performance appraisal method yearly.

- Suggestion boxes should be installed. This brings the problems or conflict of interest to light.

- Job description, responsibilities should be clear as possible. Everyone should be informed of company's goals and expectation including what is expected from each individual.

- The company should try to include appeal mechanism for complaints who are dissatisfied with the outcome of the investigator.

- The company should try to hear the suggestions of the employees for making correct decisions.

\section{Conclusion}

The study was conducted in HOMCO Ltd, Alappuzha. The study reveals that grievance handling mechanism in this adminisration is satisfactory. The company is recognizing the need to satisfy the employees and retaining them. When the draw backs are resolved then the employee's grievance can be reduced in the organization and the employees can also increase a relationship between supervisor and coworker. From this study I conclude that the employees are not satisfied with working environment in the organization. So, the organization should take some measures in order to satisfy the employees at a maximum level. Whereby it can reduce the grievance level of the employees, hence can increase and maximize the productivity.

\section{References}

[1] Dr G Balamurugan, V.Shenbagopandian "Measures in Handling Grievances from a theoritical perspective".

[2] Ms.G.Ramya, MRS K Shenbahan "Grevience Handling mechanisim and its effectiveness".

[3] Dr.V.Mohana Sundaram "Grievance handling procedure at HEME industries ltd. Hosur".

[4] Zulkiflee Bin Daurd, Khulida Kirana Yahya, Mohr faizal Mosh. Isa Wan Shakizah Wan Mohd Noor "On the influence of HOD 'S on electing grievance Handling methods".

[5] Casey Ichniowski "The Effects of Grievance Activity on Productivity".

[6] S V Mahesh krishna Radula Sahay "Does Asymmetric Information Impact Shareholder's value posetively or negatively? 